Proceeding of ICECRS, 1 (2016) 187-198

ISSN. 2548-6160

International Seminar on Generating Knowledge Through Research, UUM-UMSIDA, 25-27 October 2016, Universiti Utara Malaysia, Malaysia.

Available online: http://ojs.umsida.ac.id/index.php/icecrs

Article DOI: http://dx.doi.org/10.21070/picecrs.v1i1.595

\title{
PENGURUSAN KRISIS DI SEKOLAH DAN HUBUNGANNYA DENGAN KOMITMEN GURU SEKOLAH MENENGAH DINEGERI KELANTAN
}

\author{
Juliana Baharuddin \\ Norhana Mohammad Saad \\ Siti Noor binti Ismail \\ Pusat Pengajian Pendidikan dan Bahasa Moden, Universiti Utara Malaysia
}

\begin{abstract}
ABSTRAK: Kajian ini dijalankan untuk melihat pengurusan krisis dan hubungannya dengan komitmen guru. Responden bagi kajian ini terdiri daripada 375 orang guru daripada sekolah-sekolah menengah di negeri Kelantan. Pengurusan krisis merupakan salah satu prinsip dalam Konsep Sekolah Selamat. Instrumen kajian ini menumpukan kepada pengurusan krisis ketidakhadiran pelajar ke kelas tambahan. Instrumen komitmen guru pula menggunakan Organizational Commitment Questionnaire (OCQ) atau instrumen komitmen keorganisasian Allen dan Meyer (1990) yang telah diterjemahkan kepada Bahasa Malaysia. Segala data dan butiran yang dikumpul dianalisis menggunakan perisian Statistical Package for the Social Sciences (SPSS) Versi 22.0. Analisis data dijalankan menggunakan Ujian Min Deskriptif, Ujian-t, ANOVA Satu Hala dan Korelasi Pearson. Dapatan kajian mendapati tahap pengurusan krisis guru-guru sekolah menengah di negeri Kelantan adalah pada tahap yang tinggi dan terdapat perbezaan yang signifikan pengurusan krisis dengan kategori jawatan guru di sekolah. Tahap komitmen guru-guru sekolah menengah di negeri Kelantan pula adalah pada tahap yang sederhana. Ujian-t yang dijalankan menunjukkan tiada perbezaan yang signifikan komitmen guru antara guru lelaki dan guru perempuan di sekolah- sekolah menengah di negeri Kelantan. Hasil dapatan daripada Korelasi Pearson menunjukkan terdapat hubungan yang signifikan pengurusan krisis dengan tiga dimensi komitmen yang dibincangkan dalam kajian ini iaitu komitmen afektif, komitmen berterusan dan komitmen normatif guru-guru sekolah menengah di negeri Kelantan. Pengkaji mencadangkan agar kajian lanjutan dijalankan melibatkan sekolah rendah kebangsaan, sekolah rendah jenis kebangsaan, sekolah menengah jenis kebangsaan dan sekolah kerajaan negeri agar maklumat yang menyeluruh berkaitan pengurusan krisis dan komitmen guru di negeri Kelantan dapat digambarkan dengan lebih komprehensif. Akhir sekali, dapatan ini telah memberikan percambahan ilmu dalam bidang pengurusan krisis dan juga komitmen guru untuk dilaksanakan di sekolah
\end{abstract}

KATA KUNCI: Pengurusan krisis, Komitmen guru, Ketidakhadiran pelajar

\subsection{PENGENALAN}

Sehingga kini, profesion perguruan adalah profesion yang teramai jumlah anggotanya di negara ini. Dengan jumlah yang besar ini, maka besar jugalah masalah dalaman profesion yang dianggap tertua di dunia ini. Cabaran yang menguji profesion perguruan adakalanya datang dari dalam diri guru itu sendiri dan ada kalanya daripada faktor luar.

Krisis sekolah melibatkan semua warga sekolah, anggota masyarakat, dan turut melibatkan semua pelajar, kakitangan pejabat, pekerja kontrak dan keluarga mereka yang mempunyai kepentingan khas dalam kebajikan sekolah. Ia memberi kesan kepada bukan sahaja warga sekolah tetapi juga masyarakat keseluruhan dan komuniti (Liou, 2009). Dalam usaha untuk menangani krisis ini warga sekolah haruslah bijak dan boleh menguruskan krisis dengan berkesan. 
Pengurusan krisis yang bijak ini seterusnya akan dapat menyumbang kepada keharmonian sekolah termasuklah meningkatkan komitmen guru, menjadikan guru lebih efikasi dan bermotivasi dalam menjalankan tugas mereka seharian. Peningkatan komitmen guru ini secara tidak langsung akan turut menjadikan sekolah lebih cemerlang dan berprestasi tinggi.

\section{$2.0 \quad$ TAJUK KECIL}

\section{$2.1 \quad$ Pengurusan Krisis}

Krisis sekolah ditakrifkan sebagai peristiwa traumatik yang berkaitan dengan sekolah, sama ada peristiwa itu berlaku di dalam atau di luar kawasan sekolah serta mempunyai ciri-ciri yang tidak menentu, rumit, perlu ditangani segera (Krauss, 1998; Seeger, 2002), dan kabur (Pearson \& Clair, 1998; Simola, 2005). Krisis sekolah melibatkan semua warga sekolah, anggota masyarakat, dan turut melibatkan semua pelajar, kakitangan pejabat, pekerja kontrak dan keluarga mereka yang mempunyai kepentingan khas dalam kebajikan sekolah. Ia memberi kesan kepada bukan sahaja warga sekolah tetapi juga masyarakat keseluruhan dan komuniti (Liou, 2009). Cara konvensional yang digunakan untuk menangani krisis sering gagal kerana mereka cuba untuk mengurangkan tahap kerumitan dalam krisis dengan mengklasifikasikan tahap ketidakpastian, mengawal semua faktor yang mungkin, dan menentukan punca serta kesan (Keene, 2000; Robert \& Lajtha, 2002).

Dalam bidang pendidikan, Konsep Sekolah Selamat telah diwujudkan bagi mewujudkan iklim yang kondusif bagi memastikan pelajar dapat belajar dan guru dapat mengajar dalam suasana yang selesa dan bebas dari persekitaran yang menakutkan (Stephens, 1996). Menurut Beyer (1997) pengurusan krisis merupakan salah satu prinsip pelaksanaan Sekolah Selamat. Pelan tindak balas krisis perlu diwujudkan oleh setiap sekolah. Sekiranya perancangan bagi menangani krisis kurang bersesuaian dengan masalah yang timbul, pelan tindak balas krisis perlu diubah suai dan dilakukan penambahbaikan.

Howard (1981) menggariskan enam faktor utama yang menentukan iklim sekolah dan perlu ada dalam pengurusan krisis iaitu kepemimpinan, disiplin, keselamatan, ketidakhadiran pelajar, pengurusan konflik dan kurikulum.

Dalam mempertingkatkan mutu disiplin, guru memainkan peranan yang sangat penting. Ketidakhadiran pelajar khususnya yang melibatkan kes ponteng akan banyak memberikan kesan negatif kepada pelajar seperti kegagalan dalam pelajaran, terlibat dalam masalah sosial, vandalisme dan terlibat dalam gangsterism.

\section{$2.2 \quad$ Komitmen}

Komitmen dalam organisasi diperkenalkan oleh Becker (1960) yang kemudiannya dibincangkan oleh pengkaji-pengkaji lain dalam pelbagai cara. Komitmen pekerja terhadap organisasi adalah sangat penting kepada organisasi tersebut. Banyak kajian yang telah dijalankan mengenai komitmen guru

Dalam tingkah laku organisasi, komitmen organisasi adalah ikatan psikologi individu kepada organisasi. Banyak kajian dijalankan untuk mencari jalan bagaimana untuk menambahbaik perasaan pekerja terhadap pekerjaan mereka supaya pekerja- pekerja ini akan menjadi lebih komited kepada organisasi mereka. Komitmen organisasi boleh memberi kesan terhadap keinginan untuk bertukar tempat kerja, tingkah laku kewarganegaraan organisasi, dan prestasi kerja. Beberapa faktor seperti tekanan terhadap peranan, pengagihan kuasa, jaminan pekerjaan, dan gaya kepimpinan turut memberi kesan kepada komitmen organisasi.

Dari sudut afektif, komitmen ialah kekuatan pengenalan seseorang secara relatif dengan penglibatannya dalam organisasi yang disertainya (Mowday et. al., 1982). Manakala menurut Buchanan (1974) pula, komitmen ialah satu ikatan partisan atau afektif kepada matlamat dan nilai organisasi, peranan seseorang berhubung dengan matlamat ini dan nilai-nilai dan kepada organisasi semata-mata". Menurut Wiener (1982), dari segi pendekatan normatif pula komitmen adalah tahap tekanan normatif yang dihayati untuk 
menjalankan tugas bagi memenuhi matlamat organisasi dan kepentingannya. Terdapat banyak jenis komitmen bergantung kepada arah mana komitmen itu ditujukan. Antaranya ialah komitmen kepada organisasi, komitmen kepada pengurus atau ketua (Gregersen, 1993), komitmen kepada kerjaya (Chang, 1999), komitmen kepada kesatuan (Deery et al., 1994), komitmen kepada program (Neubert dan Cady, 2001), komitmen kepada pekerjaan atau profesion (Vanderberg dan Scarpello, 1994; Rowlinson, 2001; Wallace, 1993), komitmen kepada kerja (Aremu dan Adeyoju, 2003) dan komitmen kepada rakan sekerja (Yoon et al., 1994). Dalam perspektif Meyer dan Allen (1997), tiga jenis komitmen iaitu komitmen afektif, komitmen berterusan dan komitmen normatif.

Komitmen afektif merujuk kepada ikatan emosi pekerja, pengenalan dengan dan penglibatan dalam sesebuah organisasi. Pekerja itu terus bekerja dengan organisasi kerana mereka mahu berbuat demikian. Terdapat beberapa proses mental yang memberikan meningkatkan kepada pembangunan komitmen afektif seperti kewajaran masa lampau, penyesuaian yang bersifat klasik, hubungan sebab-musabab dan kepuasan peribadi (Meyer \& Allen, 1997).

Komitmen berterusan merujuk kepada kesedaran tentang kesan apabila meninggalkan organisasi dan faedah yang diperolehi apabila kekal dalam sebuah organisasi. Pekerja ini kekal dalam organisasi kerana mereka perlu berbuat demikian (Meyer \& Allen, 1997). Apabila membuat perkiraan, pekerja berfikir bahawa beliau akan kehilangan sesuatu jika mereka keluar daripada organisasi tersebut. Perkiraan ini melibatkan pelaburan barangan berharga (contohnya, masa, tenaga, wang) yang pekerja tersebut akan hilang jika beliau meninggalkan organisasi. Satu lagi faktor yang akan menentukan komitmen berterusan adalah persepsi tentang pilihan pekerjaan. Persepsi pekerja tentang daya maju dan ketersediaan pekerjaan lain dikaitkan secara negatif dengan komitmen berterusan. Dalam kata lain pekerja yang berfikir pilihan pekerjaan mereka adalah sedikit lebih kuat membangunkan komitmen berterusan (Meyer \& Allen, 1997). Bagi kebanyakan pekerja, antara faktor penyebab pekerja meninggalkan organisasi adalah kerana mereka sudah tua, tempoh berada dalam organisasi lebih lama dan pelaburan terkumpul mereka lebih banyak (persaraan wang, jaminan pekerjaan, status, cuti yang tidak digunakan dan lain-lain) (Allen \& Meyer, 1993; Abdullah \& Shaw, 1999), pekerja yang sudah berkahwin pula merupakan penyara keluarga dan mereka merasa meninggalkan organisasi adalah risiko yang sangat besar (Mellor et al., 2001).

Komitmen normatif mencerminkan rasa kewajipan untuk meneruskan pekerjaan. Pekerja itu merasakan bahawa mereka terhutang budi dan seharusnya kekal dengan organisasi. Komitmen jenis ini membangun atas dasar yang pengumpulan tekanan berpunca daripada nilai-nilai yang individu perolehi semasa proses sosialisasi budaya dan sosialisasi organisasi melalui penyesuaian (ganjaran dan hukuman) dan pemodelan (pemerhatian dan meniru orang lain) (Meyer \& Allen, 1997). Menurut pandangan teori pertukaran sosial, amalan organisasi yang menyokong membuat pekerja berasa dihargai dan timbul perasaan kewajipan dan terhutang budi melalui norma-norma timbal balik dan mengakibatkan peningkatan tahap komitmen normatif (Fuller et al, 2003;. Shore \& Wayne, 1993; Haar \& Eja, 2004; Wheaton, 1999; Joshi \& Stump, 1999).

Dalam kajian ini, komitmen guru-guru sekolah menengah di negeri Kelantan dinilai dalam ketiga- tiga dimensi komitmen iaitu komitmen afektif, komitmen berterusan dan komitmen normatif.

\subsection{TUJUAN KAJIAN}

Kajian ini bertujuan untuk mengenal pasti:-

i. $\quad$ Tahap pengurusan krisis guru di sekolah-sekolah menengah di negeri Kelantan.

ii. Tahap komitmen guru di sekolah-sekolah menengah di negeri Kelantan.

iii. Perbezaan pengurusan krisis guru berdasarkan kategori jawatan di sekolah.

iv. Perbezaan komitmen antara guru lelaki dan guru perempuan.

v. Hubungan antara pengurusan krisis dengan dimensi komitmen guru.

\subsection{METODOLOGI}


Untuk kajian ini, pengkaji telah memilih rekabentuk kajian deskriptif kaedah tinjauan rentasan menggunakan soal selidik. Sampel kajian ini melibatkan guru-guru di sekolah-sekolah menengah di negeri Kelantan. Kajian ini dilaksanakan di beberapa buah sekolah menengah di negeri Kelantan yang dipilih menggunakan kaedah rawak mudah. Ia melibatkan sampel seramai 375 orang guru. Bilangan sampel yang terlibat dalam kajian ini adalah berdasarkan Krejcie dan Morgan (1970) dengan mengambil kira jumlah populasi guru-guru sekolah menengah di negeri Kelantan seramai 12,996 orang.

Kajian dijalankan dengan memilih instrumen yang piawai iaitu Organizational Commitment Ouestionnaire (OCQ) atau instrumen komitmen keorganisasian Allen dan Meyer (1990). Oleh kerana instrumen asal komitmen keorganisasian adalah dalam bahasa Inggeris, maka penterjemahan perlu dilakukan oleh pakar bahasa Inggeris dan pakar bahasa Melayu secara bersilang. Sebelum instrumen ini digunakan dalam kajian sebenar, penyelidik telah membuat kajian rintis untuk menentukan kesahan dan kebolehpercayaan instrumen. Ia juga dapat mengesan item-item yang kabur dan tidak difahami (Babbie, 2001).

Instrumen penyelidikan ini mengandungi 56 item dan mengandungi empat bahagian utama iaitu Bahagian A terdiri daripada item yang berkait dengan latar belakang guru sebanyak 7 item. Bahagian B pula ialah item tentang demografi sekolah yang mengandungi 1 item. Bahagian $\mathrm{C}$ pula mengandungi item berkenaan komitmen guru sebanyak 24 item manakala Bahagian D pula terdiri daripada item- item pengurusan krisis yang juga terdiri daripada 24 item. Bagi mengukur tahap komitmen guru, item-item dalam instrumen menggunakan Skala Likert Lima mata iaitu skor 1 (sangat tidak setuju) hingga skor 5 (sangat setuju).

Untuk tujuan kajian, pakej perisian data yang boleh diperolehi secara komersil yang digunakan ialah SPSS Versi 22.0. Data-data kajian telah dianalisis menggunakan statistik deskriptif untuk menghuraikan demografi subjek kajian. Manakala Ujian-t digunakan untuk membezakan tahap komitmen guru lelaki dan guru perempuan di sekolah-sekolah menengah di negeri Kelantan. Selain itu, ANOVA digunakan untuk membezakan tahap pengurusan krisis guru mengikut kategori jawatan mereka iaitu Pentadbir, Guru Cemerlang, Guru Penyelaras Unit Kecemerlangan Akademik dan Guru Akademik.

Analisis pertama yang dijalankan ialah analisis deskriptif untuk memahami subjek sampel. Analisis deskriptif yang seterusnya pula yang dijalankan adalah untuk menilai tahap pengurusan krisis guru. Manakala analisis ketiga dibuat untuk menilai tahap komitmen guru sementara analisis keempat adalah bagi membezakan tahap pengurusan krisis antara kategori jawatan guru. Seterusnya analisis kelima dijalankan bagi membezakan tahap komitmen guru antara guru lelaki dan guru perempuan.

Analisis seterusnya adalah untuk melihat hubungan antara pengurusan krisis dengan komitmen afektif guru, pengurusan krisis dengan komitmen berterusan guru, pengurusan krisis dengan komitmen normatif guru.

\subsection{KEPUTUSAN}

Bagi memahami responden yang terlibat dalam kajian ini, pengkaji telah menjalankan analisis deskriptif bagi jantina, peringkat umur responden, kelayakan akademik, tempoh perkhidmatan sebagai guru atau pengalaman mengajar dan kategori guru yang terlibat.

Analisis deskriptif juga telah dijalankan bagi menjawab dua soalan kajian iaitu bagi mencari tahap pengurusan krisis guru di sekolah- sekolah menengah di negeri Kelantan dan tahap komitmen guru di sekolah-sekolah menengah di negeri Kelantan.

Hasil kajian mendapati tahap pengurusan krisis di kalangan guru adalah tinggi manakala, tahap komitmen guru berada pada paras sederhana. Kumpulan responden yang berumur 46-50 tahun mencatatkan tahap pengurusan krisis yang paling tinggi iaitu 32.5\% dan melibatkan seramai 122 orang responden.

Kajian ini telah menjawab persoalan kajian dan hipotesis kajian yang dibina oleh pengkaji bagi mencari tahap pengurusan krisis dan tahap komitmen guru-guru sekolah menengah di negeri Kelantan. Selain itu, kajian ini turut ingin membuktikan sama ada terdapat perbezaan pengurusan krisis antara kategori jawatan guru di sekolah. Pengkaji juga cuba mencari jika terdapat perbezaan yang signifikan komitmen antara guru lelaki 
dan guru perempuan di sekolah menengah di negeri Kelantan. Kajian ini turut memberi tumpuan kepada hubungan antara pengurusan krisis dengan tiga dimensi komitmen guru iaitu komitmen afektif, komitmen berterusan dan komitmen normatif.

Data yang diperolehi dianalisis menggunakan program SPSS Versi 22.0. Program ini membolehkan pengkaji mengenalpasti pembolehubah-pembolehubah yang terlibat dari segi kekerapan dan peratusan. Seterusnya bagi melihat sama ada terdapat perbezaan atau hubungan yang signifikan antara pembolehubahpembolehubah dalam kajian menggunakan Ujian-t, ANOVA dan Korelasi Pearson. Tahap pengurusan krisis dan tahap komitmen guru diperolehi menggunakan analisis min deskriptif. Hasil daripada kesemua ujian yang dijalankan telah berjaya menjawab kesemua persoalan kajian dan juga dapat membuktikan hipotesishipotesis yang telah dibina oleh pengkaji dalam kajian ini. Pengkaji telah menggunakan ujian-ujian yang sesuai dalam Perisian SPSS Versi 22.0 untuk menguji kesemua hipotesis tersebut.

Pengujian hipotesis yang pertama ialah untuk melihat perbezaan diantara pengurusan krisis berdasarkan kategori jawatan di sekolah menggunakan ujian ANOVA Satu Hala. Ujian tersebut adalah berdasarkan hipotesis nul seperti berikut:-

\section{$\mathrm{H}_{0} 1$ Tidak terdapat perbezaan yang signifikan pengurusan krisis berdasarkan kategori jawatan di sekolah}

Keputusan hasil ujian ANOVA Satu Hala seperti yang ditunjukkan dalam Jadual 5.1 menunjukkan terdapat perbezaan yang signifikan $[\mathrm{F}(375)=4.661 ; \mathrm{p}<0.05]$ dari segi pengurusan krisis berdasarkan kategori jawatan guru di sekolah. Hasil keputusannya, hipotesis nul adalah ditolak. Ini bermakna terdapat perbezaan yang signifikan antara pengurusan krisis dengan kategori jawatan guru di sekolah.

Jadual 5.1

Ujian ANOVA Sehala Perbezaan Pengurusan Krisis Ketidakhadiran Pelajar dengan Kategori Jawatan Guru

\begin{tabular}{cccccc}
\hline & $\begin{array}{c}\text { Jumlah Kuasa } \\
\text { Dua }\end{array}$ & $\begin{array}{c}\text { Darjah } \\
\text { Kebebasan }\end{array}$ & $\begin{array}{c}\text { Min Kuasa } \\
\text { Dua }\end{array}$ & F & Signifikan \\
\hline Antara Kumpulan & 1.122 & 3 & .374 & 4.661 & .003 \\
Dalam Kumpulan & 29.774 & 372 & .080 & & \\
Jumlah & 30.896 & 375 & & & \\
\hline
\end{tabular}

*Signifikan pada aras p $<0.05$

Perbandingan berpasangan dengan menggunakan Tukey HSD seperti di dalam Jadual 5.2 menunjukkan Pengurusan Krisis Guru Penyelaras Unit Kecemerlangan Akademik lebih baik secara signifikan berbanding kategori jawatan lain di sekolah.

Jadual 5.2

Ujian Susulan Post- hoc Test Bagi Pengurusan Krisis Ketidakhadiran Pelajar dengan Kategori Jawatan Guru

\begin{tabular}{|c|c|c|c|}
\hline (I) Kategori Jawatan & (J) Kategori Jawatan & $\begin{array}{l}\text { Perbezaan Min } \\
(\mathrm{I}-\mathrm{J})\end{array}$ & Signifikan \\
\hline \multirow[t]{4}{*}{ Pentadbir Sekolah } & Guru Cemerlang & $.29269^{*}$ & .009 \\
\hline & Penyelaras & Unit-.07419 & .881 \\
\hline & Kecemerlangan Akad & & \\
\hline & Guru Akademik & .09730 & .289 \\
\hline \multirow[t]{4}{*}{ Guru Cemerlang } & Pentadbir Sekolah & $-.29269^{*}$ & .009 \\
\hline & Penyelaras & Unit-.36688* & .008 \\
\hline & Kecemerlangan Akad & & \\
\hline & Guru Akademik & -19539 & .058 \\
\hline
\end{tabular}


Juliana Baharuddin, Norhana Mohammad Saad and Siti Noor Ismail/Proceeding of ICECRS, 1 (2016) 187198

\begin{tabular}{llll} 
Guru Penyelaras & UnitPentadbir Sekolah & .07419 & .881 \\
Kecemerlangan Akademik & Guru Cemerlang & $.36688^{*}$ & .008 \\
& Guru Akademik & .17149 & .200 \\
Guru Akademik & Pentadbir Sekolah & -.09730 & .289 \\
& Guru Cemerlang & .19539 & .058 \\
& Guru Penyelaras & Unit-.17149 & .200 \\
\hline
\end{tabular}

*Signifikan pada aras $\mathrm{p}<0.05$

Merujuk kepada perbezaan nilai min, Guru Penyelaras Akademik mempunyai tahap pengurusan krisis yang paling tinggi diikuti dengan Pentadbir dan kemudian Guru Akademik. Kesemua nilai perbezaan min bagi Guru Cemerlang yang bertanda negatif menunjukkan pengurusan krisis Guru Cemerlang paling rendah berbanding kategori jawatan guru lain di sekolah.

\section{$\mathrm{H}_{0} 2$ Tidak terdapat perbezaan yang signifikan tahap komitmen guru antara guru lelaki dan guru perempuan}

Bagi pembuktian hipotesis yang kedua, pengkaji telah memilih Ujian-t. Ujian-t dipilih kerana pembolehubah yang terlibat adalah yang mempunyai data selanjar dan data jenis kategori dengan dua kumpulan sahaja.

Merujuk kepada Jadual 5.3, didapati terdapat perbezaan yang sangat kecil nilai min tahap komitmen guru lelaki dan guru perempuan dimana tahap min guru lelaki adalah $(\mathrm{M}=3.42$, $\mathrm{SP}=.34)$ dan tahap min guru perempuan adalah $(\mathrm{M}=3.40, \mathrm{SP}=.30)$.

Jadual 5.3

Ujian- t Perbezaan Komitmen Guru Berdasarkan Jantina

\begin{tabular}{lllll}
\hline & Jantina & $\mathrm{N}$ & Min & SP \\
\hline Komitmen Guru & Lelaki & 179 & 3.4197 & .33954 \\
& Perempuan & 195 & 3.4004 & .30464
\end{tabular}

Merujuk kepada Jadual 5.4, nilai F .001 adalah tidak signifikan, oleh itu pengkaji akan menganggap varian Lelaki dan Perempuan adalah sama.

Jadual 5.4

Ujian Levene untuk Persamaan Varian

Ujian Levene untuk Kesamaan Varian

\begin{tabular}{llll} 
& & F & Sig. \\
\hline Komitmen Guru & Varian dianggap sama & .001 & .974 \\
& Varian dianggap tidak sama & & \\
\hline
\end{tabular}

Berdasarkan Jadual 5.5, nilai $\mathrm{p}>0.05$ iaitu tidak signifikan. Oleh itu, hipotesis nul diterima. Maka, tidak terdapat perbezaan yang signifikan antara komitmen guru lelaki dan guru perempuan. 
Juliana Baharuddin, Norhana Mohammad Saad and Siti Noor Ismail/Proceeding of ICECRS, 1 (2016) 187198

Jadual 5.5

Persamaan Min Bagi Ujian- $t$

Min Bagi Persamaan Ujian- $\mathrm{t}$

\begin{tabular}{lllll} 
& & SP & Sig. (2-hujung) & Perbezaan Min \\
\hline \multirow{2}{*}{ Komitmen Guru } & Varian dianggap sama & 372 & .563 & .01927 \\
& Varian dianggap tidak sama 358.60 & .565 & .01927 \\
\hline
\end{tabular}

$\mathrm{H}_{0} 3$ Tidak terdapat hubungan yang signifikan pengurusan krisis dengan komitmen afektif guru

Pembuktian hipotesis ketiga dilakukan menggunakan Korelasi Pearson. Korelasi Pearson dipilih kerana kedua-dua pembolehubah merupakan data selanjar.

Jadual 5.6

Min Deskriptif Bagi Pengurusan Krisis dengan Komitmen Afektif Guru

\begin{tabular}{cccc}
\hline & Min & SP & N \\
\hline Pengurusan Krisis & 3.8376 & .28742 & 375 \\
Komitmen Afektif & 3.3904 & .44627 & 374 \\
\hline
\end{tabular}

Merujuk kepada Jadual 5.6 diatas, tahap pengurusan krisis adalah tinggi manakala tahap komitmen afektif pula adalah sederhana.

Penyelidik menggunakan skala anggaran kekuatan perhubungan antara dua pemboleh ubah pada Jadual 5.7 daripada Alias Baba (1997) untuk menentukan tahap hubungan dalam menganalisis dapatan kumpulan data yang dianalisa.

Jadual 5.7

Jadual Skala Anggaran Kekuatan Perhubungan Antara Pemboleh ubah

\begin{tabular}{ll}
\hline Aras Hubungan & Tahap Hubungan \\
\hline $0.00-0.20$ & Lemah \\
$0.21-0.40$ & Rendah \\
$0.41-0.60$ & Sederhana \\
$0.61-0.80$ & Tinggi \\
$0.81-1.00$ & Sangat Tinggi \\
\hline
\end{tabular}

(Sumber: Alias Baba, 1997)

Jadual 5.8

Korelasi Pearson Bagi Pengurusan Krisis dengan Komitmen Afektif Guru

\begin{tabular}{llll}
\hline & & $\begin{array}{l}\text { Pengurusan } \\
\text { Krisis }\end{array}$ & Komitmen Afektif \\
\hline Pengurusan Krisis & Korelasi Pearson & 1 & $.249^{* *}$ \\
& Signifikan (2-hujung) & & .000 \\
& $\mathrm{~N}$ & 375 & 374 \\
Komitmen Afektif & Korelasi Pearson & $.249^{* *}$ & 1 \\
\hline \hline
\end{tabular}




\begin{tabular}{ccc} 
Signifikan (2-hujung) & .000 \\
$\mathrm{~N}$ & 374 & 374 \\
\hline **. Korelasi adalah signifikan pada aras 0.01 (2-hujung).
\end{tabular}

**. Korelasi adalah signifikan pada aras 0.01 (2-hujung).

Jadual 5.8 menunjukkan analisis korelasi Pearson antara Pengurusan Krisis dan Komitmen Afektif Guru. Dapatan menunjukkan pekali korelasi, $r$ bagi Pengurusan Krisis dan Komitmen Afektif Guru adalah $r=.25$ menunjukkan kekuatan hubungan yang rendah antara pengurusan krisis dan komitmen afektif guru. Nilai signifikan, $\mathrm{p}(.000)$ dimana $\mathrm{p}<0.01$ adalah signifikan dan menunjukkan hipotesis nul ditolak. Maka, ini bermakna terdapat hubungan yang signifikan antara Pengurusan Krisis dan Komitmen Afektif Guru.

H04 Tidak terdapat hubungan yang signifikan pengurusan krisis dengan komitmen berterusan guru.

Pembuktian hipotesis keempat dilakukan menggunakan Korelasi Pearson. Korelasi Pearson dipilih kerana kedua-dua pembolehubah merupakan data selanjar.

Jadual 5.9

Min Deskriptif Pengurusan Krisis dengan Komitmen Berterusan Guru

\begin{tabular}{llll}
\hline & Min & SP & N \\
\hline Pengurusan Krisis & 3.8376 & .28742 & 375 \\
Komitmen Berterusan & 3.2660 & .45087 & 375 \\
\hline
\end{tabular}

Merujuk kepada Jadual 5.9 diatas, tahap pengurusan krisis adalah tinggi manakala tahap komitmen berterusan pula adalah sederhana.

Jadual 5.10

Korelasi Pearson Bagi Pengurusan Krisis dengan Komitmen Berterusan Guru

\begin{tabular}{llll}
\hline & & $\begin{array}{l}\text { Pengurusan } \\
\text { Krisis }\end{array}$ & $\begin{array}{l}\text { Komitmen } \\
\text { Berterusan }\end{array}$ \\
\hline Pengurusan Krisis & Korelasi Pearson & 1 & $.359^{* *}$ \\
& Signifikan (2-hujung) & & .000 \\
& $\mathrm{~N}$ & 375 & 375 \\
Komitmen Berterusan & Korelasi Pearson & $.359^{* *}$ & 1 \\
& Signifikan (2-hujung) & .000 & \\
& $\mathrm{~N}$ & 375 & 375 \\
\hline
\end{tabular}

**. Korelasi adalah signifikan pada aras 0.01 (2-hujung).

Jadual 5.10 menunjukkan analisis korelasi Pearson antara Pengurusan Krisis dan Komitmen Berterusan Guru. Dapatan menunjukkan pekali korelasi, $r$ bagi Pengurusan Krisis dan Komitmen Afektif Guru adalah $r=.359$. Menurut Alias Baba (1997), nilai ini menunjukkan kekuatan hubungan yang rendah. Nilai signifikan, p (.000) dimana $\mathrm{p}<0.01$ adalah signifikan dan menunjukkan hipotesis nul ditolak. Maka, ini bermakna terdapat hubungan yang signifikan antara Pengurusan Krisis dan Komitmen Berterusan Guru.

\section{$\mathrm{H}_{0} 5$ Tidak terdapat hubungan yang signifikan pengurusan krisis dengan komitmen normatif guru.}

Pembuktian hipotesis kelima dilakukan menggunakan Korelasi Pearson. Korelasi Pearson dipilih kerana kedua-dua pembolehubah merupakan data selanjar. 
Juliana Baharuddin, Norhana Mohammad Saad and Siti Noor Ismail/Proceeding of ICECRS, 1 (2016) 187198

Jadual 5.11

Min Deskriptif Pengurusan Krisis dengan Komitmen Normatif Guru

\begin{tabular}{llll}
\hline & Min & SP & N \\
\hline Pengurusan Krisis & 3.8376 & .28742 & 375 \\
Komitmen Normatif & 3.5720 & .42775 & 375 \\
\hline
\end{tabular}

Merujuk kepada Jadual 5.11 diatas, tahap pengurusan krisis adalah tinggi manakala tahap komitmen normatif pula adalah sederhana.

Jadual 5.12

Korelasi Pearson Bagi Pengurusan Krisis dengan Komitmen Normatif Guru

\begin{tabular}{llll}
\hline & & $\begin{array}{l}\text { Pengurusan } \\
\text { Krisis }\end{array}$ & $\begin{array}{l}\text { Komitmen } \\
\text { Normatif }\end{array}$ \\
\hline Pengurusan Krisis & Korelasi Pearson & 1 & $.352^{* *}$ \\
& Signifikan (2-hujung) & & .000 \\
Komitmen Normatif & 375 & 375 \\
& K & $.352^{* *}$ & 1 \\
& Korelasi Pearson & .000 & \\
& Signifikan (2-hujung) & 375 & 375 \\
& $\mathrm{~N}$ & & \\
\hline
\end{tabular}

Jadual 5.12 menunjukkan analisis korelasi antara Pengurusan Krisis dan Komitmen Normatif Guru. Dapatan menunjukkan pekali korelasi, $r$ bagi Pengurusan Krisis dan Komitmen Normatif Guru adalah $r=.38$ dan nilai ini menunjukkan kekuatan hubungan yang rendah. Nilai signifikan, $p(.000)$ dimana $p<0.01$ adalah signifikan dan menunjukkan hipotesis nul ditolak. Maka, ini bermakna terdapat hubungan yang signifikan antara Pengurusan Krisis dan Komitmen Normatif Guru.

\subsection{PERBINCANGAN DAN RUMUSAN}

Berdasarkan dapatan kajian yang dijalankan, tahap pengurusan krisis di kalangan guru- guru adalah pada tahap yang tinggi. Hipotesis pertama dalam kajian ini telah dibuktikan dan pengkaji mendapati terdapat perbezaan yang signifikan antara pengurusan krisis dengan kategori jawatan guru di sekolah. Guru Penyelaras Kecemerlangan Akademik mampu menguruskan krisis dengan paling baik berbanding kategori jawatan lain di sekolah diikuti oleh pentadbir, guru akademik dan akhir sekali guru cemerlang. Di sekolah, Guru Penyelaras Kecemerlangan Akademik akan merancang program untuk memastikan kecemerlangan akademik pelajar, termasuklah mengadakan kelas tambahan. Jika timbul sebarang krisis, mereka adalah orang pertama yang akan dirujuk dan mereka juga merupakan orang pertama yang akan menguruskan krisis tersebut. Mereka kemudiannya akan berbincang dengan pentadbir tentang krisis yang timbul tersebut.

Dapatan kajian ini selari dengan kenyataan Woodstock dan Francis (1993) yang mengatakan bahawa komitmen guru akan merudum jika cabaran menjadi kurang. Ini kerana seseorang guru itu telah tahu bahawa kebanyakan tuntutan dapat diatasi dengan segera kerana pengalaman yang banyak. Oleh itu pemimpin sekolah perlu dengan melibatkan guru dalam pengurusan krisis disekolah bagi memberi suntikan cabaran dalam tugas guru di sekolah. Pengurusan krisis akan menjadi rangsangan kepada peningkatan 
komitmen guru di sekolah kerana ia merupakan satu cabaran dan bukanlah suatu perkara rutin yang dilakukan oleh guru saban hari.

Kajian ini turut mendapati tahap komitmen guru adalah pada tahap yang sederhana dan tahap komitmen guru perempuan adalah lebih tinggi jika dibandingkan dengan guru lelaki. Namun, perbezaan itu adalah sangat kecil. Hipotesis kedua dalam kajian ini pula turut membuktikan bahawa tidak terdapat perbezaan yang signifikan antara komitmen guru lelaki dan guru perempuan.

Dapatan kajian ini tidak selari dengan dapatan kajian oleh Mehmet (2008) yang menyatakan terdapat perbezaan yang signifikan tahap komitmen guru lelaki dan guru perempuan di sekolah. Menurut Mehmet (2008) fokus komitmen guru, jenis dan tahap komitmen bergantung kepada ciri peribadi individu tersebut seperti jantina, status perkahwinan dan pengalaman bekerja. Walaupun guru perempuan adalah lebih komited dari segi afektif dan normatif kepada organisasi pendidikan berbanding guru lelaki, namun mereka mempunyai tahap komitmen normatif yang rendah terhadap kumpulan kerja dan komitmen berterusan yang rendah kepada sekolah tempat mereka berkhidmat kerana kurang pelaburan. Guru yang sudah berkahwin juga kurang komitmen afektif dan komitmen normatif berbanding guru yang belum berkahwin. Namun, guru yang sudah berkahwin mempunyai komitmen berterusan yang tinggi terhadap profesion perguruan dan sekolah tempat mereka berkhidmat. Apabila pengalaman bekerja guru meningkat, pelaburan yang dibuat terhadap sekolah turut meningkat. Oleh yang demikian, komitmen berterusan guru- guru yang berpengalaman ini terhadap sekolah tempat mereka berkhidmat adalah tinggi. Walaupun guru yang mempunyai pengalaman kerja 1 hingga 5 tahun mempunyai komitmen normatif yang tinggi terhadap profesion mereka, tetapi mereka mempunyai komitmen afektif dan komitmen normatif yang paling rendah terhadap kumpulan kerja.

Dapatan kajian ini menyokong dapatan kajian Siti Shamzela, Shahman dan Yaakob, Daud (2012) yang telah menjalankan kajian untuk mengenal pasti tahap komitmen organisasi, efikasi kendiri dan kepuasan kerja guru-guru di dua jenis sekolah iaitu sekolah menengah berprestasi tinggi (SBT) dan sekolah menengah berprestasi rendah (SBR). Kajian tersebut mendapati tahap komitmen guru berada pada paras sederhana dan terdapat perbezaan yang signifikan komitmen organisasi guru di SBT dan SBR. Dapatan kajian tersebut adalah selari dengan dapatan kajian ini yang menunjukkan tahap komitmen guru adalah pada paras sederhana.

Hipotesis ketiga, keempat dan kelima telah dibuktikan menggunakan Korelasi Pearson dimana ketiga- tiga hipotesis ini ingin mencari hubungan antara pengurusan krisis dengan tiga dimensi dalam komitmen guru. Hipotesis ketiga membuktikan terdapat hubungan yang signifikan antara pengurusan krisis dan komitmen afektif. Namun, hubungan tersebut adalah lemah. Hipotesis keempat dan kelima pula membuktikan terdapat hubungan yang signifikan antara pengurusan krisis dengan komitmen berterusan dan komitmen normatif dimana kedua- duanya menunjukkan hubungan yang sederhana.

Dapatan kajian ini bertepatan dengan dapatan kajian Dworkin (1987) yang telah menjalankan kajian ke atas guru-guru di Wilayah Timur Amerika Syarikat dan mendapati 50 peratus daripada responden akan menukar kerja lain jika diberi peluang. Ini menunjukkan tahap komitmen berterusan yang lemah jika guru tidak dilibatkan dalam pengurusan krisis di sekolah. Menurut penemuan kajian tersebut antara puncanya penurunan tahap komitmen berterusan guru adalah kerana terlalu banyak masa diperlukan untuk kerja-kerja perkeranian, gaji yang tidak memuaskan, dan tidak mendapat kerjasama daripada rakan sejawat. Guru tidak dilibatkan dalam pengurusan krisis di sekolah dan hanya pengurus sekolah boleh terlibat dalam pengurusan krisis.

Satu kajian lain yang telah dijalankan oleh Castillo (1999) mengenai sikap dan minat terhadap profesion perguruan dalam kalangan guru-guru pertanian di Ohio juga mempunyai dapatan yang selari dengan kajian yang dijalankan ini. Beliau telah mendapati bahawa guru- guru tidak puas hati dengan keadaan kemudahan yang disediakan di sekolah. Guru juga tidak berpuas hati terhadap beban tugas yang kian bertambah dan menyebabkan mereka tidak mempunyai masa untuk menyelaraskan aktiviti yang lebih kreatif. Mereka juga 
tidak dilibatkan dalam pengurusan krisis. Dalam kajian beliau, Castillo juga mendapati bahawa sebanyak $55 \%$ responden kajian memilih profesion perguruan kerana gagal mendapat pekerjaan lain. Perkara yang lebih menyedihkan adalah lebih kurang $47 \%$ responden akan meninggalkan kerjaya ini jika mendapat pilihan lain. Komitmen normatif yang rendah ini sedikit sebanyak dipengaruhi oleh faktor dimana guru tidak dilibatkan dalam pengurusan krisis tetapi dilambakkan dengan tugas- tugas lain yang tidak releven dengan kehendak guru itu sendiri.

Dapatan kajian ini menyokong hasil dapatan kajian Lim (2005) telah membuktikan bahawa sesetengah guru memang mengalami tekanan perasaan dan telah memikirkan atau mengambil keputusan untuk berhenti atau bersara sebelum sampai umur persaraan disebabkan ketidakpuasan kerja, peranan yang kabur terhadap kerja. Guru akan merasa lebih dihargai apabila dilibatkan dalam proses membuat keputusan dan pengurusan krisis di sekolah. Mereka akan lebih bersemangat dan jelas dengan peranan yang perlu dimainkan dalam pengurusan krisis di sekolah bagi menjana kecemerlangan sekolah. Hal ini akan meningkatkan tahap komitmen guru dan guru akan memilih untuk kekal dalam organisasi tersebut.

Dapatan kajian ini seiring dengan teori Bass (1985) yang menyatakan pemimpin sekolah yang melibatkan guru dalam pengurusan krisis akan dapat meningkatkan komitmen guru tersebut. Menurut Bass (1985) gaya kepimpinan transformasi lebih mengutamakan hubungan erat pemimpin- pengikut. Keeratan hubungan ini boleh berlaku apabila pengikut diberi tanggung jawab dan autoriti, halangan-halangan birokratik yang boleh menjejaskan keeratan hubungan pemimpin-pengikut dihapuskan, latihan dan nasihat disediakan khususnya dalam pengurusan krisis termasuk proses membuat keputusan dan menyelesaikan masalah. Pemimpin ini juga menggalakkan komunikasi terbuka supaya perkongsian idea-idea dan maklumat penting dapat dilakukan. Semua tindakan ini bertujuan supaya pengikut merasa seronok, sentiasa bermotivasi dan mempunyai komitmen yang tinggi terhadap tugas.

Dapatan kajian ini bertepatan dengan pengurusan krisis dalam konsep Sekolah Selamat dimana Azman Adnan (2014) menyatakan guru-guru, pelajar dan komuniti boleh memainkan peranan dengan cara mengambil bahagian dalam pelbagai program pengukuhan disiplin di sekolah termasuk memastikan murid menghadiri kelas tambahan di sekolah. Melalui cara ini akan tertanam rasa kepunyaan terhadap program tersebut lantas membangkitkan komitmen untuk terus berusaha bersungguh- sungguh menjayakan program tersebut. Dalam kajian yang sama, Azman Adnan (2014) menggariskan beberapa implikasi Sekolah Selamat yang antaranya akan menjadikan komuniti merasai kepunyaan terhadap sekolah, kecuaian dapat dielakkan dan komitmen bekerja sentiasa tinggi.

\section{RUJUKAN}

Allen, N. J. (2003). Organizational commitment in the military: A Discussion of Theory and Practice, Military Psychology, Vol. 15, pp. 237-253.

Allen, N. J. \& Meyer, J. P. (1990). The measurement and antecedents of affective, continuance, and normative commitment. Journal of Occupational Phychology, 63, 1- 18.

Allen, N. J. \& Meyer, J. P. (1996). Affective, continuance, and normative commitment to the organization: an examination of construct validity. Journal of Vocational Behaviour, 49, 252- 276.

Arnold, K.A., Barling, K., and Kelloway, E. K. (2001). Transformational leadership or the iron cage: Which predicts trust, commitment and team efficacy? . Leadership and Organizational Development Journal, $22,315-320$

Azizan Talib et. al. (2002) Konsep dan manual sekolah selamat: Panduan pelaksanaan menjadikan sekolah, komuniti dan keluarga selamat untuk anak- anak. Bahagian Sekolah, Kementerian Pendidikan Malaysia.

Azman Adnan. (2014). Safe school: Konsep dan implementasinya di sekolah. Bahagian Sekolah, Kementerian Pendidikan Malaysia

Babbie, E. (2001). The practice of social research, 9th Edition. Belmont, CA: McGraw- Hill

Bass, B. M. (1985). Leadership and performance beyond expectations. New York Free Press.

Becker, H. (1960). Notes on the concept of commitment. American Journal of Sociology, Vol. 66, pp. 32-42.

Cronbach, L. J. (1951). Coefficient alpha and the internal structure of tests. Psychometrika, 16(3), 297-334.

Dworkin, G. (1987). Ethics and Entrapment. Journal of Social Issues, Vol 43(3), 57-59 
Juliana Baharuddin, Norhana Mohammad Saad and Siti Noor Ismail/Proceeding of ICECRS, 1 (2016) 187198

Gainey, B. S. (2010). Crisis management's new role in educational settings. The Clearing House: A Journal of Educational Strategies, Issues and Ideas, 8 (26), 267- 274

Ghitulescu, B E. (2012). Making change happen: The ipact of work context on Adaptive and Proactive Behaviours. The Journal of Applied Behavioural Sciences, 49 (2), 206- 245.

Hackett, R. D., Bycio, P., and Hausdorf, P. A. (1994). Further assessments of Meyer Allen's (1991) threecomponent model of organizational commitment. Journal of applied psychology, 79 (1), 15-23

Harris, P. (2010). Crisis management. Pierce Transit, Lakewood, Washington

Rahaman, S. (2012). Organizational commitment, perceived organizational support, and job satisfaction among school teachers: comparing public and private sectors in Bangladesh.South Asian Journal of Management 19 (3)

Iverson, R. D., and Buttigieg, D. N. (1998). Affective, normative and continuance commitment: Can the right kind of commitment be managed? University of Melbourne

King, G. (2002) . Crisis management \& team effectiveness: A closer examination. Journal of Business Ethics, 41 (3), 235- 247.

Komal Nagar (2012). Organizational commitment and job satisfaction among teachers during times of burnout. Vikalpa: The Journal for Decision Makers, Vol 37(2), pg 43

Mehmet, K. (2008). Teachers Commitment focuses: A three dimensoned view. Journal of Management Development, 28(5)

Meier, S. L; Hovde, R. L; Meier, R. L. (1996). Problem solving: Teachers' perceptions, content area models, and interdiciplinary connections.ProQuest Educational Journals, 96 (5), pg 230- 236

Meyer, J. P and Herscovitch, L. (2001) Commitment in the work place: Toward a general model. Human Resources Management Review, 11, 299- 326

Mohd Khairuddin Mohd Ashaari. (1998). Amalan kebersihan sekolah: Panduan aktiviti. Kementerian Pendidikan Malaysia.

Mohd Yusri Ibrahim. (2010). Bimbingan cepat analisis data penyelidikan: Pendidikan Sains Sosial. Bandar Ilmu. Kuantan

Msila, V. (2013). In search of a liberating practice: Leadership, teachers' commitment and the struggle for effective schools. ISEA, Vol 41, 95 - 105.

Nunnally, J. C. (1978). Psychometric theory (2nd ed.). New York: McGraw-Hill.

NorSyirin Md Mokhtar et. al. (2004). Persediaan menghadapi bencana. Bahagian Sekolah, KPM dengan kerjasama UNICEF

Ruhaya Hassan. (2011). Jurnal kajian tindakan: Pengurusan dan kepimpinan Pendidikan, 14 (2)

Rusmini Ku Ahmad. (2006). Hubungan antara kepimpinan, komitmen guru, kompetensi guru,amalan-amalan terbaik dan keberkesanan sekolah, tesis PHD, Universiti Utara Malaysia.

Shamsiah Mohd Amin, Shahrulbanun A. Ghani, Azaiah Ab. Latif. (2005). Konsep Pelaksanaan Sekolah Selamat. Universiti Teknologi Malaysia.

Shukri Zain. (2004). Sekolah selamat dan identifikasi profesionalisme guru. Jurnal Pengurusan dan Kepimpinan Pendidikan, 14 (2)

Siti Shamzela, Shahman Yaakob, Daud. (2012). Komitmen organisasi, efikasi kendiri dan kepuasan kerja guruguru sekolah berprestasi tinggi dan sekolah berprestasi rendah di Kuala Krai, Kelantan. thesis, Universiti Utara Malaysia

TALIS. (2000). Creating Effective Teaching and Learning Environments: First Results .TALIS - ISBN 978-92-6405605-3

Tanko Ahmed. (2014). Crisis management: The art of problem solving.NIPSS, Kuru

Treffinger, Donald J., Isaksen, Scott G. (2005). Creative problem solving: The history, development, and implications. ProQuest Educational Journals, 49 (4), pg 342- 350

Wilson, T. D. (1999). Models in information behaviour research. Journal of Documentation, 55 (3), 249- 270.

Wooter, L. P., James, E.H. (2008) . Linking Crisis Management and leadership competencies: The role of human resorce development. Advances in Developing Human Resouce, Vol 10, No. 3, 352- 379 